\title{
Protective Effect of Rifampicin against Acute Liver Injury Induced by Carbon Tetrachloride in Mice
}

\author{
Renbin Huang, Hiroyasu Okuno, Masashi Takasu, Yasuko Shiozaki and Kyoichi Inoue \\ Third Department of Internal Medicine, Kansai Medical University, Fumizono-cho 10-15, Moriguchi, Osaka 570, Japan \\ Received June 30, 1995 Accepted September 13, 1995
}

\begin{abstract}
Rifampicin conferred significant protection against carbon tetrachloride $\left(\mathrm{CCl}_{4}\right)$-induced liver injury. Serum alanine transaminase (ALT) and aspartate transaminase (AST) activities were not markedly altered and only hepatocellular fatty degeneration was found in mice pretreated with rifampicin (200 $\mathrm{mg} / \mathrm{kg}$ ), whereas severe centrilobular necrosis was observed and serum ALT and AST activities were as high as 281 and 271 I.U./l, respectively, in the control group following administration of $\mathrm{CCl}_{4}(400 \mu \mathrm{l} / \mathrm{kg})$. The contents and activities of microsomal drug-metabolizing enzymes in rifampicin-pretreated animals were also much higher than those of the controls. $\mathrm{CCl}_{4}$-mediated malondialdehyde (MDA) formation was increased in rifampicin-treated liver microsomes, demonstrating that rifampicin was capable of increasing the NADPH-dependent metabolism of $\mathrm{CCl}_{4}$ catalyzed by P-450 2E1 to produce free radicals. However, MDA formation was obviously depressed by rifampicin at varying concentrations from 2 to $32 \times 10^{-6} \mathrm{M}$ in an in vitro cytochrome P-450 (P-450) enzyme system. On the other hand, NADPH oxidation in the metabolism of $\mathrm{CCl}_{4}$ and aniline hydroxylation were not suppressed in the presence of rifampicin in this systems, suggesting that rifampicin did not influence the biotransformation of $\mathrm{CCl}_{4}$ by $\mathrm{P}-4502 \mathrm{E} 1$ in vitro. Therefore, the protective effect of rifampicin against $\mathrm{CCl}_{4}$ hepatotoxicity appeared to result from the direct inhibition of lipid peroxidation generated by $\mathrm{CCl}_{4}$-derived free radicals.
\end{abstract}

Keywords: Rifampicin, Carbon tetrachloride, Cytochrome P-450, Liver injury, Malondialdehyde

Rifampicin, an antituberculosis drug, is usually administered for a long period with other antituberculosis drugs or medication from other classes. It was recently reported that rifampicin significantly relieved pruritus in adult patients with primary biliary cirrhosis and children with cholestatic liver disease $(1,2)$. The potential for drug interaction often exists because rifampicin is a potent inducer of liver microsomal drug-metabolizing enzymes, as demonstrated by proliferation of smooth endoplasmic reticulum and an increase in cytochrome P-450 (P-450) in the liver (3). Clinically important drug interactions have been documented between rifampicin and numerous other drugs such as oral anticoagulants, oral contraceptives, several antiarrhythmics, cyclosporine and digitalis (4). Rifampicin accelerates the biotransformation of various other compounds and decreases their plasma concentration, efficacy and half-life by induction of microsomal enzymes. In contrast, Adachi et al. (5) reported that liver bilirubin-conjugating enzymes were induced by rifampicin, but mixed-function oxidases, including P-450, cytochrome $b_{5}$, aniline hydroxylase and aminopyrine $N$-de- methylase, were not induced in rats.

As reported previously, phenobarbital enhanced biotransformation of carbon tetrachloride $\left(\mathrm{CCl}_{4}\right)$ to bioactive metabolites that cause liver injury by induction of hepatic mixed-function oxidase. It is not understood whether rifampicin, as an inducer of microsomal enzymes, can potentiate $\mathrm{CCl}_{4}$ hepatotoxicity. In this study, we investigated the effects and mechanism of rifampicin on liver damage induced by $\mathrm{CCl}_{4}$ and compared the differences between the effects of rifampicin and phenobarbital on $\mathrm{CCl}_{4}$ hepatotoxicity and hepatic microsomal enzymes in mice.

\section{MATERIALS AND METHODS}

\section{Chemicals and reagents}

Rifampicin and serum alanine transaminase (ALT) and aspartate transaminase (AST) kits were purchased from Wako Pure Chemical Industries Ltd., Osaka. Phenobarbital was obtained from Tokyo Kasei Kogyo Co., Tokyo. $\mathrm{CCl}_{4}$ was purchased from Nacalai Tesque, Inc., Kyoto. 
NADPH and NADH were obtained from Kohjin Co., Ltd., Tokyo. Cytochrome c was purchased from Sigma Chemical Co. (St. Louis, MO, USA).

\section{Animals and treatments}

Male Crj:CD-1 (ICR) mice, 24-26g (Charles River Japan, Yokohama), were used. Animals were housed in a temperature-controlled room and fed a standard diet. Rifampicin dissolved in $0.02 \mathrm{~N} \mathrm{HCl}$ was administered orally to mice at doses of 50,100 and $200 \mathrm{mg} / \mathrm{kg}$ for four days. Phenobarbital dissolved in distilled water was injected intraperitoneally at a dose of $80 \mathrm{mg} / \mathrm{kg}$ on four consecutive days. $\mathrm{CCl}_{4}$ dissolved in olive oil with an injection volume of $5 \mathrm{ml} / \mathrm{kg}$ was given subcutaneously at a single dose of $50,100,200$ or $400 \mu \mathrm{l} / \mathrm{kg}$ in different groups. The last dose of inducer and $\mathrm{CCl}_{4}$ were given concurrently in the cotreatment groups. The animals were sacrificed $20 \mathrm{hr}$ after treatment with $\mathrm{CCl}_{4}$ or the last dose of rifampicin and phenobarbital.

\section{Preparation of liver microsomes}

The livers were removed immediately, perfused with cold $0.15 \mathrm{M} \mathrm{KCl}$ and homogenized in 4 volumes of 0.15 $\mathrm{M} \mathrm{KCl}$ solution containing $10 \mathrm{mM}$ EDTA using a Pottertype Teflon glass homogenizer. The homogenate was centrifuged at $10,000 \times \mathrm{g}$ for $15 \mathrm{~min}$ in a refrigerated centrifuge (KR/20000; Kubota, Tokyo). The supernatant was then centrifuged at $105,000 \times g$ for $60 \mathrm{~min}$ in a preparative ultracentrifuge (70P-I; Hitachi, Tokyo). The pellet of microsomes was suspended in the homogenization solution in homogenizer and centrifuged again as described above. The resulting pellet was suspended in $20 \mathrm{mM}$ potassium phosphate buffer ( $\mathrm{pH} \mathrm{7.4)} \mathrm{containing}$ $15 \%$ glycerol. These procedures were performed at $0{ }^{\circ} \mathrm{C}-4{ }^{\circ} \mathrm{C}$.

Biochemical liver function tests and microsomal enzyme assays

The activities of serum ALT and AST were measured by the UV Rate method and expressed as international units per liter. The contents of serum total protein and liver microsomal protein were determined by the method of Lowry et al. (6). The content of P-450 was measured by the method of Omura and Sato (7). The content of cytochrome $b_{5}$ and the activity of NADPH-cytochrome $c$ reductase were assayed as described by Omura and Takesue (8) using a spectrophotometer (DU-64; Beckman, Fullerton, CA, USA).

Substrate-metabolizing enzyme activities, aniline hydroxylation, aminopyrine $\mathrm{N}$-demethylation, 7-ethoxycoumarin (7-EC) and 7-methoxycoumarin (7-MC) $O$ dealkylation, and benzo(a)pyrene (B(a)P) hydroxylation were measured as described by Imai et al. (9), Nash (10),
Ullrich and Weber (11) and Nebert and Gelboin (12), respectively. Each substrate-metabolizing enzyme activity was assayed using NADPH as the sole electron source.

\section{Measurement of malondialdehyde (MDA) formation}

In vitro metabolism of $\mathrm{CCl}_{4}$ was determined by measuring $\mathrm{CCl}_{4}$-dependent lipid peroxidation in the monooxygenase system prepared from mouse livers according to the thiobarbituric acid assay (13). Incubation was carried out with liver microsomes $(1 \mathrm{mg} / \mathrm{ml})$ in $100 \mathrm{mM}$ potassium phosphate buffer ( $\mathrm{pH} 7.4$ ), containing $0.4 \mathrm{mM}$ $\mathrm{NADPH}$ and $10 \mathrm{mM} \mathrm{CCl}_{4}$ (dissolved in methanol), in a final volume of $1 \mathrm{ml}$. Methanol was used in the reference tube. Inhibition of MDA production by rifampicin was assayed as described above. Rifampicin was added to the reaction mixtures at varying concentrations of $0.5,2,8$ and $32 \times 10^{-6} \mathrm{M}$. The comparative inhibitory effect of rifampicin and glutathione (GSH) on MDA formation was determined by the same method. The final concentrations of rifampicin and GSH in vitro were varied from $2.2 \times 10^{-7}$ to $10^{-4} \mathrm{M}$ and $4.6 \times 10^{-6}$ to $10^{-3} \mathrm{M}$, respectively. The reaction was started by the addition of $\mathrm{NADPH}$ and $\mathrm{CCl}_{4}$ concurrently with vigorous shaking after preincubation at $37^{\circ} \mathrm{C}$ for $3 \mathrm{~min}$, and it was stopped by $30 \%$ trichloroacetic acid after incubation for $6 \mathrm{~min}$. Thiobarbituric acid reactive substance MDA was expressed as $\mathrm{nmol} / \mathrm{mg}$ microsomal protein (MS Pr.) $/ \mathrm{min}$.

\section{Determination of NADPH oxidation}

NADPH oxidation during metabolism of $\mathrm{CCl}_{4}$ was assayed in an in vitro P-450 enzyme system. The incubation mixture consisted of $100 \mathrm{mM}$ potassium phosphate buffer (pH 7.4), liver microsomes $(1 \mathrm{mg} / \mathrm{ml}), 5 \mathrm{mM} \mathrm{CCl}_{4}$ dissolved in methanol and $0.1 \mathrm{mM}$ NADPH. The reference mixture received vehicle alone. The effect of rifampicin on the oxidative metabolism of NADPH was assayed as described above in the presence of rifampicin at a concentration of $8 \times 10^{-6} \mathrm{M}$. The reaction was started by adding $\mathrm{CCl}_{4}$ and NADPH concurrently after preincubation at $37^{\circ} \mathrm{C}$ for $3 \mathrm{~min}$. NADPH disappearance was monitored fluorometrically for $3 \mathrm{~min}$ at $450 \mathrm{~nm}$ with an excitation wavelength of $365 \mathrm{~nm}$ (13) using a fluorescence spectrophotometer (Hitachi 650-60).

\section{Effect of rifampicin on aniline hydroxylase activity in vitro}

Aniline hydroxylase activity was assayed according to the method of Imai et al. (9). Incubation was carried out with liver microsomes $(1 \mathrm{mg} / \mathrm{ml})$ in $100 \mathrm{mM}$ Tris-acetate buffer ( $\mathrm{pH} 8.0$ ), containing $3 \mathrm{mM} \mathrm{MgCl}_{2}, 2 \mathrm{mM}$ aniline and $1 \mathrm{mM}$ NADPH, in a final volume of $0.5 \mathrm{ml}$. The effect of rifampicin on aniline hydroxylase activity was assayed as described above in the presence of rifampicin 
at a concentration of $8 \times 10^{-6} \mathrm{M}$. The reaction was started by addition of NADPH with vigorous shaking after preincubation at $37^{\circ} \mathrm{C}$ for $3 \mathrm{~min}$, and it was stopped by $20 \%$ trichloroacetic acid after incubation for $15 \mathrm{~min}$.

\section{Histopathology}

Livers were fixed in neutral 10\% formalin. Tissues were routinely processed and embedded in paraffin. Sections were stained with hematoxylin and eosin and then examined histopathologically by light microscopy.

\section{Statistical analyses}

All values are expressed as means \pm S.D. Data were analyzed by Wilcoxon's test for unpaired variables. Differences were considered statistically significant when $\mathrm{P}<0.05$.

\section{RESULTS}

\section{Effects of rifampicin on biochemical liver functions}

The effects of rifampicin on serum biochemical parameters in mice treated with and without $\mathrm{CCl}_{4}$ are shown in Fig. 1, Table 1 and Table 2. Serum ALT and AST activities were not significantly altered in the rifampicin (RFP)- and phenobarbital-treated groups. In mice with liver injury induced by $\mathrm{CCl}_{4}$, serum ALT and AST were markedly elevated by increasing the dose of $\mathrm{CCl}_{4}$ to 281 and 272 I.U./ $\left(\mathrm{CCl}_{4}, 400 \mu \mathrm{l} / \mathrm{kg}\right)$, respectively, whereas these activities rose only to 70 and 47 I.U./1 (RFP, $200 \mathrm{mg} / \mathrm{kg}$ ) and 150 and 159 I.U./1 (RFP, 100 $\mathrm{mg} / \mathrm{kg}$ ), respectively, at the same dose of $\mathrm{CCl}_{4}$ in the rifampicin-pretreated group. The serum levels of ALT and AST in the other rifampicin-pretreated groups (200 $\mathrm{mg} / \mathrm{kg}$ ) were also much lower than those in the corresponding $\mathrm{CCl}_{4}$-treated groups at the same dose of $\mathrm{CCl}_{4}$. The activities of serum ALT and AST in the groups that received combination treatment with phenobarbital and $\mathrm{CCl}_{4}$ were not significantly different from those of the controls at low doses of $\mathrm{CCl}_{4}(50$ and $100 \mu \mathrm{l} / \mathrm{kg})$, but they were much higher than those in the controls on treatment with a high dose: serum ALT and AST were as high as 532 and 460 I.U. $/$, respectively, at the dose of $400 \mu \mathrm{l} / \mathrm{kg}$
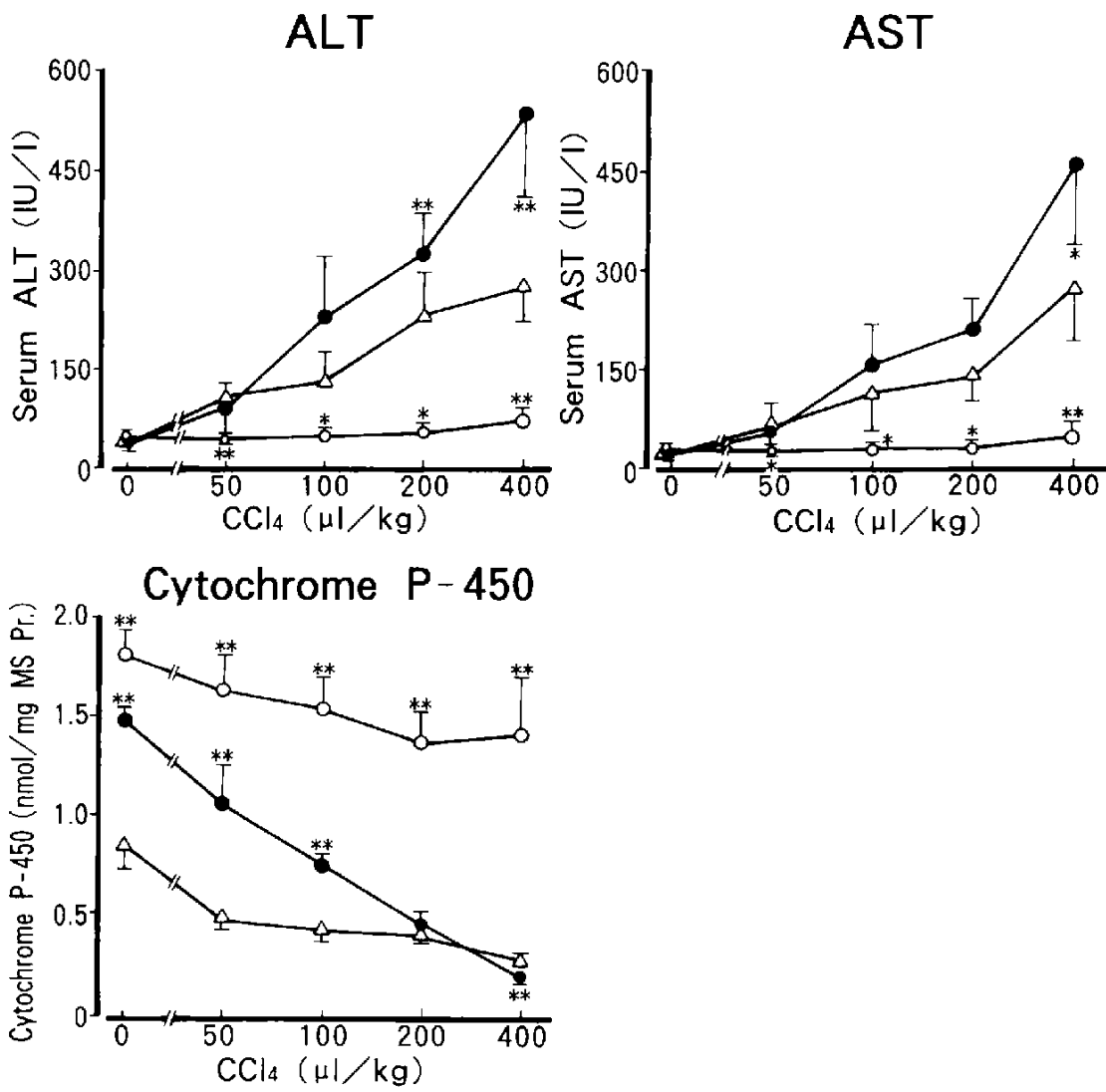

Fig. 1. Effects of rifampicin on serum ALT and AST activities and content of $\mathrm{P} 450$ in mice treated with and without $\mathrm{CCl}_{4}$. Rifampicin (RFP) and phenobarbital (PB) were given at doses of 200 and $80 \mathrm{mg} / \mathrm{kg}$, respectively, for 4 days. Values represent means \pm S.D., $\mathrm{n}=5$ animals. ${ }^{*} \mathrm{P}<0.05,{ }^{* *} \mathrm{P}<0.01$ : RFP- and PB-treated groups are compared with the untreated group; $\mathrm{RFP}+\mathrm{CCl}_{4}$ - and $\mathrm{PB}+\mathrm{CCl}_{4}$-treated groups are compared with the corresponding same dose of $\mathrm{CCl}_{4}$ alone-treated group. RFPand $\mathrm{RFP}+\mathrm{CCl}_{4}$-treated groups $(\bigcirc), \mathrm{PB}$ and $\mathrm{PB}+\mathrm{CCl}_{4}(\bigcirc)$, untreated and $\mathrm{CCl}_{4}$ alone $(\triangle)$. 
Table 1. Effects of rifampicin on the contents of serum total protein, microsomal protein and cytochrome $b_{5}$ and the activity of NADPH-cytochrome $\mathrm{c}$ reductase in mice treated with and without $\mathrm{CCl}_{4}$

\begin{tabular}{lllllc}
\hline Group & & $\begin{array}{l}\text { Serum total } \\
\text { protein } \\
(\mathrm{g} / \mathrm{l})\end{array}$ & $\begin{array}{l}\text { Microsomal } \\
\text { protein } \\
(\mathrm{mg} / \mathrm{g} \text { liver })\end{array}$ & $\begin{array}{c}\text { Cytochrome } \mathrm{b}_{5} \\
(\mathrm{nmol} / \mathrm{mg} \mathrm{MS} \mathrm{Pr} \text { ) }\end{array}$ & $\begin{array}{c}\text { NADPH-Cyt. c } \\
\text { reductase } \\
\text { (nmol/mg MS Pr./min) }\end{array}$ \\
\hline Untreated & $(\mathrm{n}=5)$ & $60.92 \pm 5.50$ & $19.66 \pm 1.04$ & $0.328 \pm 0.030$ & $82.90 \pm 12.89$ \\
$\mathrm{CCl}_{4}: 50$ & $(\mathrm{n}=5)$ & $62.39 \pm 3.63$ & $21.76 \pm 1.71$ & $0.261 \pm 0.018$ & $64.06 \pm 13.61$ \\
$\mathrm{CCl}_{4}: 100$ & $(\mathrm{n}=5)$ & $60.14 \pm 4.38$ & $16.90 \pm 1.52$ & $0.245 \pm 0.035$ & $65.92 \pm 14.09$ \\
$\mathrm{CCl}_{4}: 200$ & $(\mathrm{n}=5)$ & $59.90 \pm 2.24$ & $16.74 \pm 1.37$ & $0.197 \pm 0.043$ & $58.92 \pm 5.56$ \\
$\mathrm{CCl}_{4}: 400$ & $(\mathrm{n}=5)$ & $62.47 \pm 6.02$ & $17.02 \pm 1.52$ & $0.191 \pm 0.008$ & $54.04 \pm 3.84$ \\
$\mathrm{~PB}$ & $(\mathrm{n}=5)$ & $61.01 \pm 4.70$ & $26.54 \pm 3.37^{* *}$ & $0.433 \pm 0.032^{* *}$ & $136.78 \pm 9.06^{* *}$ \\
$\mathrm{~PB}+\mathrm{CCl}_{4}: 50$ & $(\mathrm{n}=5)$ & $63.76 \pm 5.86$ & $22.26 \pm 2.80^{*}$ & $0.382 \pm 0.043^{* *}$ & $122.66 \pm 17.96^{* *}$ \\
$\mathrm{~PB}+\mathrm{CCl}_{4}: 100$ & $(\mathrm{n}=5)$ & $60.22 \pm 3.72$ & $20.77 \pm 1.24^{*}$ & $0.376 \pm 0.064^{*}$ & $112.71 \pm 29.00^{*}$ \\
$\mathrm{~PB}+\mathrm{CCl}_{4}: 200$ & $(\mathrm{n}=5)$ & $60.37 \pm 6.31$ & $17.98 \pm 2.10$ & $0.307 \pm 0.049^{*}$ & $86.82 \pm 18.03^{*}$ \\
$\mathrm{~PB}+\mathrm{CCl}_{4}: 400$ & $(\mathrm{n}=5)$ & $62.70 \pm 4.36$ & $16.93 \pm 1.24$ & $0.210 \pm 0.031$ & $70.82 \pm 8.52^{* *}$ \\
$\mathrm{RFP}$ & $(\mathrm{n}=5)$ & $66.43 \pm 6.25$ & $22.69 \pm 3.12$ & $0.457 \pm 0.069^{*}$ & $157.06 \pm 5.63^{* *}$ \\
$\mathrm{RFP}+\mathrm{CCl}_{4}: 50$ & $(\mathrm{n}=5)$ & $63.71 \pm 6.59$ & $25.51 \pm 1.91^{* *}$ & $0.397 \pm 0.056^{* *}$ & $139.39 \pm 13.02^{* *}$ \\
$\mathrm{RFP}+\mathrm{CCl}_{4}: 100$ & $(\mathrm{n}=4)$ & $63.83 \pm 4.93$ & $23.78 \pm 2.62^{* *}$ & $0.426 \pm 0.055^{* *}$ & $145.74 \pm 30.58^{* *}$ \\
$\mathrm{RFP}+\mathrm{CCl}_{4}: 200$ & $(\mathrm{n}=4)$ & $62.35 \pm 4.78$ & $21.82 \pm 4.34^{*}$ & $0.423 \pm 0.066^{* *}$ & $139.52 \pm 23.33^{* *}$ \\
$\mathrm{RFP}+\mathrm{CCl}_{4}: 400$ & $(\mathrm{n}=5)$ & $63.86 \pm 6.65$ & $22.04 \pm 1.42^{*}$ & $0.410 \pm 0.039^{* *}$ & $148.44 \pm 13.83^{* *}$ \\
\hline
\end{tabular}

The numbers following the colons are doses of $\mathrm{CCl}_{4}(\mu 1 / \mathrm{kg})$. Rifampicin (RFP) and phenobarbital (PB) were administered at doses of 200 and $80 \mathrm{mg} / \mathrm{kg}$, respectively, for 4 days. Values represent means \pm S.D. ${ }^{*} \mathbf{P}<0.05$, ${ }^{* *} \mathrm{P}<0.01$ : PB- and RFP-treated groups are compared with the untreated group, and $\mathrm{PB}+\mathrm{CCl}_{4^{-}}$and $\mathrm{RFP}+\mathrm{CCl}_{4^{-}}$ treated groups are compared with the corresponding same dose of $\mathrm{CCl}_{4}$ alone-treated groups.

Table 2. Effect of varying doses of rifampicin on serum ALT and AST activities and the content of P -450

\begin{tabular}{lcccc}
\hline Group & & $\begin{array}{c}\text { ALT } \\
(\mathrm{I} . \mathrm{U} . / \mathrm{l})\end{array}$ & $\begin{array}{c}\text { AST } \\
(\mathrm{I} . \mathrm{U} . / \mathrm{l})\end{array}$ & $\begin{array}{c}\text { P-450 } \\
(\mathrm{nmol} / \mathrm{mg} \mathrm{MS} \text { Pr. })\end{array}$ \\
\hline Untreated & $(\mathrm{n}=5)$ & $40.25 \pm 4.69^{* *}$ & $21.65 \pm 4.17^{* *}$ & $0.853 \pm 0.126^{* *}$ \\
$\mathrm{CCl}_{4}$ & $(\mathrm{n}=5)$ & $280.63 \pm 58.17$ & $271.36 \pm 78.00$ & $0.293 \pm 0.033$ \\
$\mathrm{CCl}_{4}+$ RFP:50 & $(\mathrm{n}=5)$ & $292.42 \pm 79.64$ & $287.88 \pm 90.44$ & $0.525 \pm 0.153^{* *}$ \\
$\mathrm{CCl}_{4}+$ RFP:100 & $(\mathrm{n}=5)$ & $150.14 \pm 58.18^{*}$ & $159.35 \pm 71.39^{*}$ & $0.979 \pm 0.128^{* *}$ \\
$\mathrm{CCl}_{4}+$ RFP:200 & $(\mathrm{n}=5)$ & $70.23 \pm 23.75^{* *}$ & $46.57 \pm 24.49^{* *}$ & $1.421 \pm 0.289^{* *}$ \\
\hline
\end{tabular}

Rifampicin (RFP) was administered for 4 days, and the numbers following the colons are doses of $\mathrm{RFP}(\mathrm{mg} / \mathrm{kg}) . \mathrm{CCl}_{4}$ was given at a single dose of $400 \mu 1 / \mathrm{kg}$. Values represent means $\pm \mathrm{S} . \mathrm{D} .{ }^{*} \mathrm{P}<0.05$, **P<0.01: compared with the $\mathrm{CCl}_{4}$ alone-treated group.

$\mathrm{CCl}_{4}$. The content of serum total protein was increased by $9 \%$ in the rifampicin-treated group $(200 \mathrm{mg} / \mathrm{kg})$, but this was not significantly different from that in untreated mice. There was no obvious change in the content of serum total protein in the groups cotreated with rifampicin or phenobarbital and $\mathrm{CCl}_{4}$, which was similar to that in animals that received the hepatotoxin alone.

Effect of rifampicin on the contents of P-450 and cytochrome $b_{5}$ and the activity of NADPH-cytochrome $c$ reductase

As shown in Fig. 1, rifampicin and phenobarbital increased the content of P- 450 by $110 \%$ and $72 \%$, respec- tively. After administration of $\mathrm{CCl}_{4}$, the content of P-450 was decreased obviously at varying doses from 50 to 400 $\mu \mathrm{l} / \mathrm{kg}$ in the $\mathrm{CCl}_{4}$-treated groups. In mice pretreated with phenobarbital, although P-450 was markedly induced prior to use of $\mathrm{CCl}_{4}$, it was also dose-dependently reduced after $\mathrm{CCl}_{4}$, and was much lower than in the control at a dose of $400 \mu \mathrm{l} / \mathrm{kg}$. The amount of P-450 was slightly affected in the groups pretreated with rifampicin (200 $\mathrm{mg} / \mathrm{kg}$ ), the decrease in which was much less than in other groups following treatment with $\mathrm{CCl}_{4}$. The contents of $\mathrm{P}-450$ in the groups pretreated with rifampicin (200 $\mathrm{mg} / \mathrm{kg}$ ) and phenobarbital were $485 \%$ and $72 \%$ of the control level $\left(\mathrm{CCl}_{4}, 400 \mu \mathrm{l} / \mathrm{kg}\right)$, respectively. As shown in 
Table 2, the P-450 content was reduced to a certain extent in mice pretreated with rifampicin at doses of 50 and 100 $\mathrm{mg} / \mathrm{kg}$ after dosing with $\mathrm{CCl}_{4}$, but it remained much higher than in the group treated with $\mathrm{CCl}_{4}$ alone.

The contents of microsomal protein and cytochrome $\mathrm{b}_{5}$ and the activity of NADPH-cytochrome $\mathrm{c}$ reductase are shown in Table 1. Rifampicin and phenobarbital were capable of inducing increases in the contents of microsomal protein and cytochrome $b_{5}$ and the activity of NADPH-cytochrome $\mathrm{c}$ reductase, which were $135 \%$,
$132 \%$ and $165 \%$ of the control values in phenobarbitaltreated mice, respectively, and $115 \%, 139 \%$ and $189 \%$ of the controls in rifampicin-treated mice, respectively. After administration of $\mathrm{CCl}_{4}$, the contents of microsomal protein and cytochrome $b_{5}$ and the activity of NADPHcytochrome $c$ reductase were markedly reduced in the mice treated with $\mathrm{CCl}_{4}$ alone and cotreated with phenobarbital and $\mathrm{CCl}_{4}$, especially at high $\mathrm{CCl}_{4}$ doses. In contrast, these values were not obviously reduced in the groups cotreated with rifampicin and $\mathrm{CCl}_{4}$. The contents
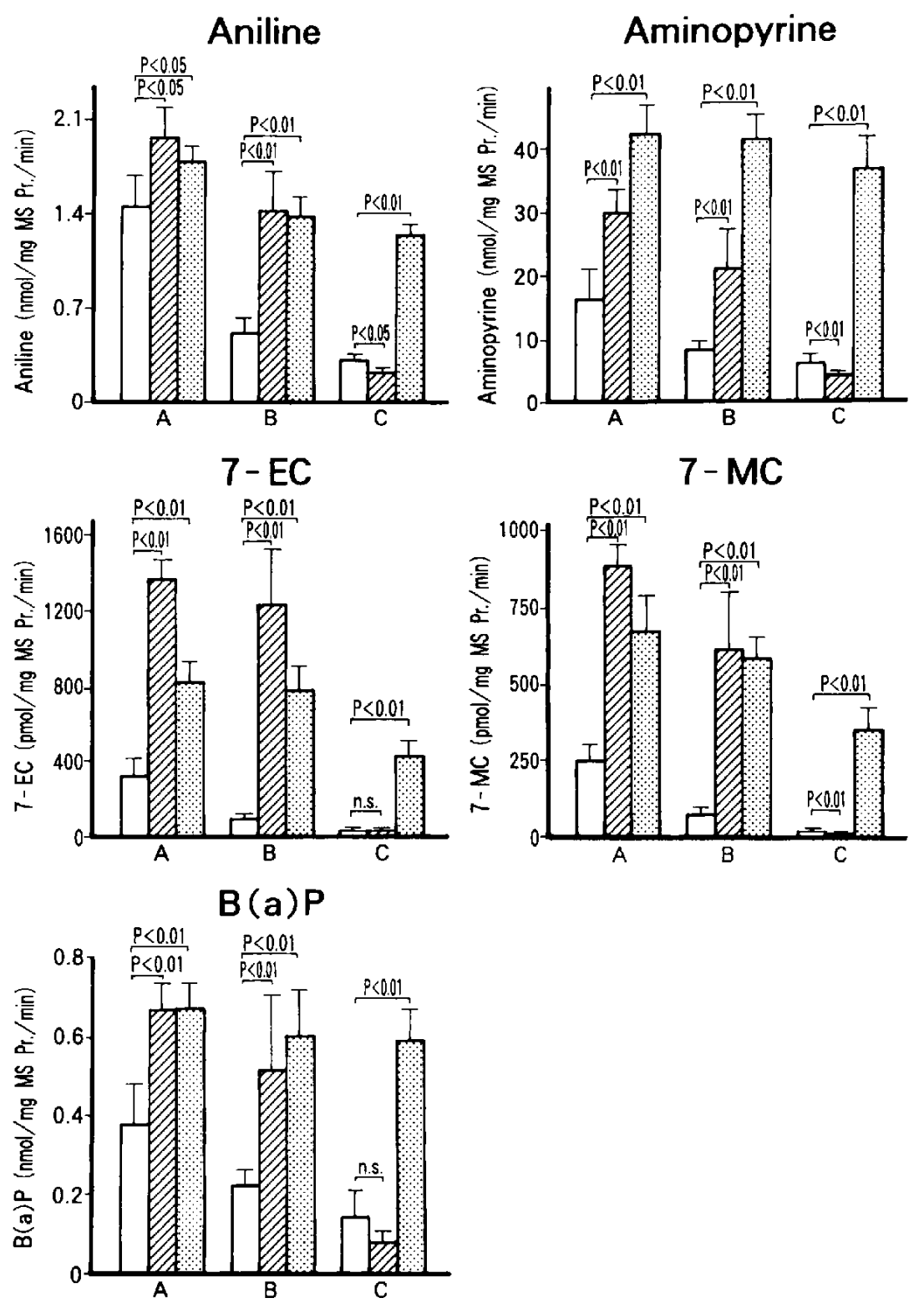

Fig. 2. Effects of rifampicin on the activities of drug-metabolizing enzymes in mice treated with and without $\mathrm{CCl}_{4}$. Rifampicin (RFP) and phenobarbital (PB) were given at doses of 200 and $80 \mathrm{mg} / \mathrm{kg}$, respectively, for 4 days. Each column represents a mean \pm S.D. Columns A represent untreated $(\square)$, PB ( $\square$ )- and RFP ( $\square$ )-treated groups; Columns B represent CCl $(50 \mu \mathrm{l} / \mathrm{kg}$,

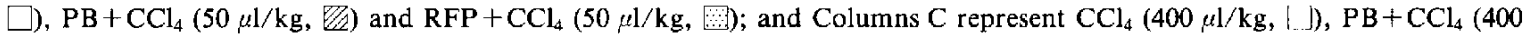
$\mu \mathrm{l} / \mathrm{kg}, \bigotimes)$ and $\mathrm{RFP}+\mathrm{CCl}_{4}(400 \mu \mathrm{l} / \mathrm{kg}, \mathrm{i})$. 
of microsomal protein and cytochrome $b_{5}$ and the activity of NADPH-cytochrome c reductase were $129 \%, 215 \%$ and $275 \%$ of the control levels, respectively, in animals that received combination treatment with rifampicin and $\mathrm{CCl}_{4}$, and $99 \%, 110 \%$ and $131 \%$ of the controls in those that received combination treatment with phenobarbital and $\mathrm{CCl}_{4}$ at a dose of $400 \mu \mathrm{l} / \mathrm{kg} \mathrm{CCl}$, respectively.

\section{Effects of rifampicin on drug-metabolizing enzyme activ- ities}

Rifampicin is an inducer of the activities of aniline hydroxylase, aminopyrine $\mathrm{N}$-demethylase, 7-EC and 7MC O-dealkylases and B(a)P hydroxylase (Fig. 2). As compared with phenobarbital treatment, the effects of rifampicin on the activities of drug-metabolizing enzymes were less marked with the exception of aminopyrine $\mathrm{N}$-demethylase, the activity of which was higher in rifampicin-treated mice than that in those treated with phenobarbital, and $\mathrm{B}(\mathrm{a}) \mathrm{P}$ hydroxylase which was the same in both groups. The activities of drug-metabolizing enzymes were markedly reduced in the groups treated with $\mathrm{CCl}_{4}$ alone and cotreated with phenobarbital and $\mathrm{CCl}_{4}$, but the degree of decline was greater in the former at the dose of $50 \mu \mathrm{l} / \mathrm{kg}$ of $\mathrm{CCl}_{4}$. After treatment with $\mathrm{CCl}_{4}$, although the activities of these enzymes in the animals cotreated with rifampicin and $\mathrm{CCl}_{4}$ were also decreased to a certain extent, they remained much higher than control levels. At a dose of $400 \mu 1 / \mathrm{kg}$ of $\mathrm{CCl}_{4}$, the activities of aniline hydroxylase, aminopyrine $\mathrm{N}$-demethylase, 7-EC and 7-MC $O$-dealkylases and $\mathrm{B}(\mathrm{a}) \mathrm{P}$ hydroxylase were $390 \%, 604 \%, 1260 \%, 1910 \%$ and $394 \%$ of controls, respectively, in the mice cotreated with rifampicin and $\mathrm{CCl}_{4}$. In contrast, these values were only $72 \%, 67 \%, 106 \%, 31 \%$ and $54 \%$ of the controls, respectively, in the group with cotreatment with phenobarbital and $\mathrm{CCl}_{4}$.

Table 3. Stimulation of lipid peroxidation by $\mathrm{CCl}_{4}$ in the in vitro $\mathrm{P}-450$ enzyme systems prepared from untreated and inducer-treated mice

\begin{tabular}{lccr}
\hline Group & & $\begin{array}{c}\text { MDA } \\
(\mathrm{nmol} / \mathrm{mg} \text { MS Pr./min) }\end{array}$ & \% control \\
\hline Untreated & $(\mathrm{n}=5)$ & $1.036 \pm 0.248$ & 100.0 \\
Phenobarbital & $(\mathrm{n}=5)$ & $1.921 \pm 0.423^{* *}$ & 185.4 \\
Rifampicin & $(\mathrm{n}=5)$ & $1.502 \pm 0.063^{* *}$ & 144.9 \\
$\mathrm{CCl}_{4}$ & $(\mathrm{n}=5)$ & $0.101 \pm 0.030^{* *}$ & 9.7 \\
\hline
\end{tabular}

Microsomes were prepared from untreated, phenobarbital (80 $\mathrm{mg} / \mathrm{kg}$ for 4 days)-, rifampicin (200 mg/ $\mathrm{kg}$ for 4 days)- and $\mathrm{CCl}_{4}$ $\left(400 \mu \mathrm{l} / \mathrm{kg}\right.$ )-treated mice. Values represent means \pm S.D. ${ }^{* *} \mathrm{P}<0.01$ : compared with the untreated group.
$\mathrm{CCl}_{4}$-dependent $\mathrm{MDA}$ formation and inhibition of its formation by rifampicin in an in vitro monooxygenase system

As shown in Table 3, the stimulation of lipid peroxidation by $\mathrm{CCl}_{4}$ was noticeably enhanced in the in vitro P-450 enzyme systems prepared from rifampicin- and phenobarbital-induced mice, especially from the latter, whereas it was almost suppressed in the system from $\mathrm{CCl}_{4}$-intoxicated animals $\left(\mathrm{CCl}_{4}, 400 \mu \mathrm{l} / \mathrm{kg}\right)$. MDA production was $185 \%, 145 \%$ and $10 \%$ of control level in the phenobarbital-, rifampicin- and $\mathrm{CCl}_{4}(400 \mu \mathrm{l} / \mathrm{kg})$ treated P-450 enzyme systems, respectively.

Rifampicin is a powerful inhibitor of $\mathrm{CCl}_{4}$-dependent MDA formation. NADPH-linked lipid peroxidation was significantly depressed in the presence of rifampicin at varying concentrations of 2,8 and $32 \times 10^{-6} \mathrm{M}$ in the in vitro P-450 enzyme systems prepared from untreated and inducer-treated mice. A similar inhibitory effect, which was markedly increased with elevation of concentration, was obtained in the three enzyme systems described above, with rifampicin treatment. Inhibitory rates of rifampicin at a concentration of $32 \times 10^{-6} \mathrm{M}$ on MDA production were $79 \%, 83 \%$ and $79 \%$ in untreated,

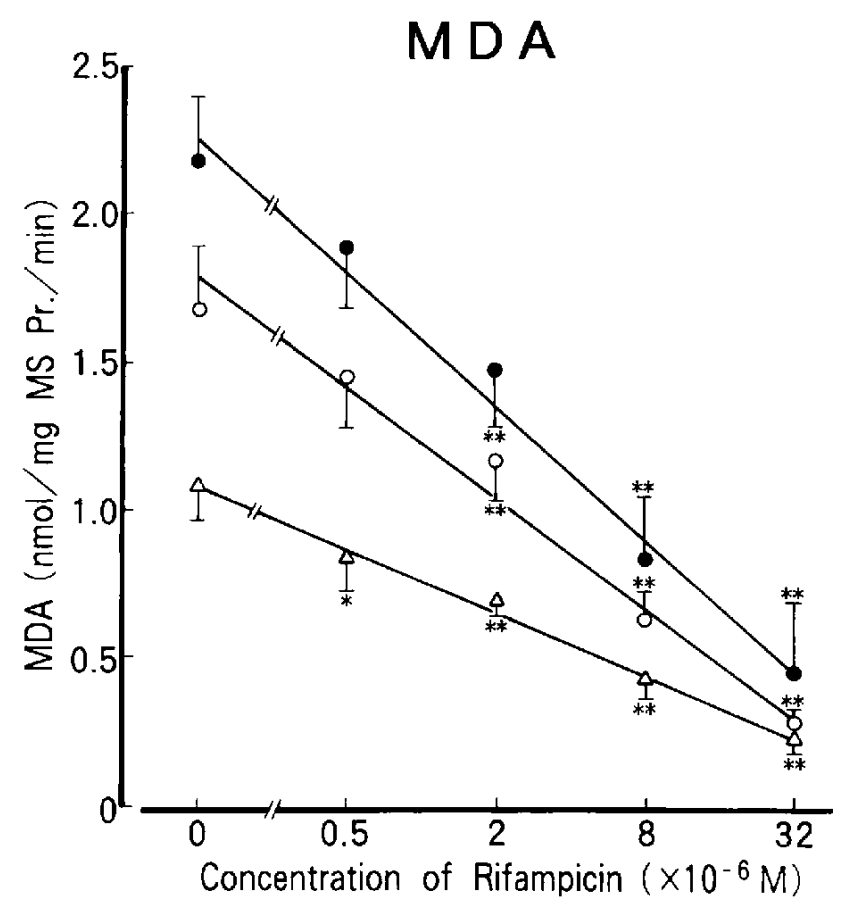

Fig. 3. Inhibition by rifampicin of MDA formation stimulated by $\mathrm{CCl}_{4}$ in the in vitro P-450 enzyme systems. Microsomes were prepared from untreated $(\triangle, n=5)$, rifampicin $(\bigcirc, n=5)-$ and phenobarbital $(O, n=4)$-treated groups. Rifampicin and phenobarbital were given at doses of 200 and $80 \mathrm{mg} / \mathrm{kg}$, respectively, for 4 days. $\mathrm{CCl}_{4}$ was given at a single dose of $400 \mu \mathrm{l} / \mathrm{kg}$. Values represent means \pm S.D. ${ }^{*} \mathrm{P}<0.05,{ }^{* *} \mathrm{P}<0.01$ : compared with the respective value of each group in the absence of rifampicin in vitro. 


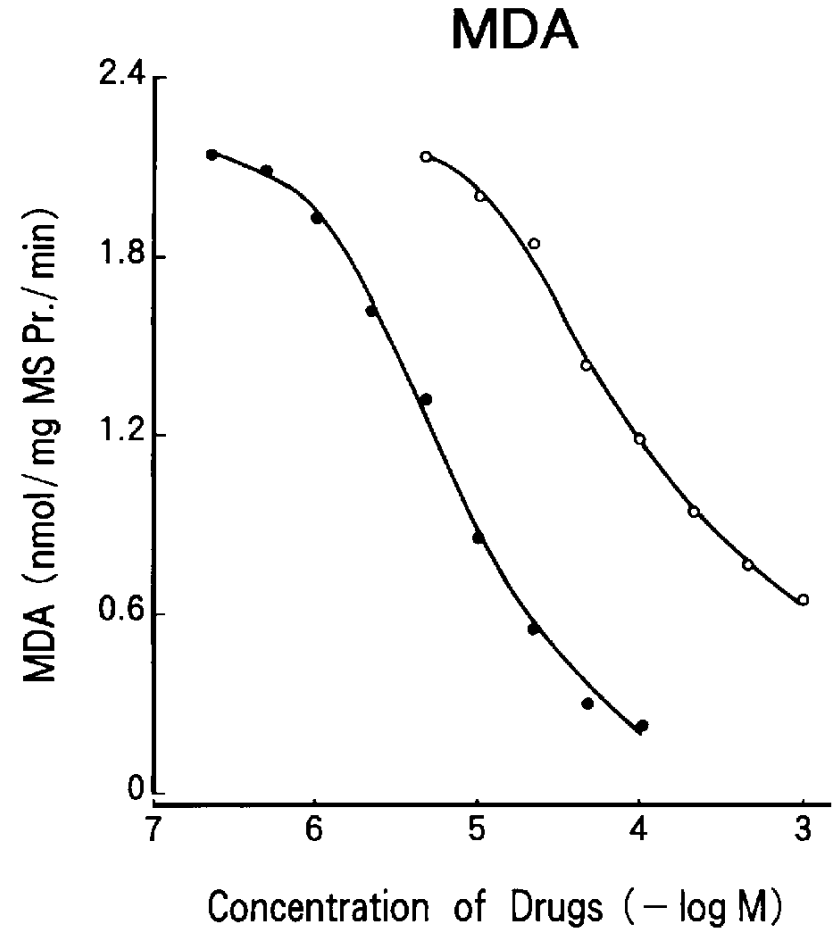

Fig. 4. Comparison of inhibition by rifampicin and GSH of MDA formation mediated by $\mathrm{CCl}_{4}$ in the in vitro $\mathrm{P}-450$ enzyme system. Microsomes were prepared from mice treated with phenobarbital at dose of $80 \mathrm{mg} / \mathrm{kg}$ for 4 days. The final concentrations of rifampicin (O) and GSH $(\bigcirc)$ in vitro were varied from $2.2 \times 10^{-7}$ to $10^{-4} \mathrm{M}$ and from $4.6 \times 10^{-6}$ to $10^{-3} \mathrm{M}$, respectively. Each point is the mean value of duplicate assays.

rifampicin- and phenobarbital-induced enzyme systems, respectively, as shown in Fig. 3. GSH showed a similar inhibitory effect on $\mathrm{CCl}_{4}$-generated lipid peroxidation as rifampicin did. The $50 \%$ inhibitory concentration $\left(\mathrm{IC}_{50}\right)$ of rifampicin and $\mathrm{GSH}$ on $\mathrm{CCl}_{4}$-mediated MDA formation in phenobarbital-induced microsomes of mice was $6 \times 10^{-6}$ and $10^{-4} \mathrm{M}$, respectively, the former being much lower than the latter (Fig. 4).
Effect of rifampicin on NADPH oxidation in the metabolism of $\mathrm{CCl}_{4}$ and aniline hydroxylase activity in the in vitro monooxygenase system

The results are shown in Table 4, NADPH oxidation in the metabolism of $\mathrm{CCl}_{4}$ and aniline hydroxylation were markedly increased in the in vitro P-450 enzyme systems prepared from rifampicin- and phenobarbital-induced mice, while they were obviously diminished in the system prepared from the $\mathrm{CCl}_{4}$-treated group. In the presence of rifampicin at a concentration of $8 \times 10^{-6} \mathrm{M}$, which markedly suppressed $\mathrm{CCl}_{4}$-dependent MDA formation in these systems, NADPH oxidation and aniline hydroxylase activity were not significantly different from the control values.

\section{Histopathological findings}

Histopathological examination revealed that cytoplasmic vacuoles were present in hepatocytes, indicating fatty degeneration in mice treated with rifampicin alone (200 $\mathrm{mg} / \mathrm{kg}$ ) and in those cotreated with rifampicin (200 $\mathrm{mg} / \mathrm{kg})$ and $\mathrm{CCl}_{4}(400 \mu \mathrm{l} / \mathrm{kg})$, but there was no significant difference between the two groups. Severe centrilobular necrosis of the liver was observed in mice treated with $\mathrm{CCl}_{4}$ alone and in those cotreated with phenobarbital and $\mathrm{CCl}_{4}$, and the necrosis was more severe in the latter at a dose of $400 \mu \mathrm{l} / \mathrm{kg}$. Mice treated with phenobarbital alone had normal liver histology.

\section{DISCUSSION}

Rifampicin is a potent inducer of hepatic microsomal enzymes, and it has been shown to increase cytochrome (CYP, gene) 3A6 gene expression in rabbits (14) and elevate the CYP1A1 mRNA level and rate of transcription in cycloheximide-treated rabbit hepatocytes (15). The present study showed that rifampicin elevated the contents of P-450 and cytochrome $b_{5}$, and the activities of NADPH-cytochrome $c$ reductase and drug-metabolizing

Table 4. Effect of rifampicin on NADPH oxidation in the metabolism of $\mathrm{CCl}_{4}$ and aniline hydroxylase activity in the in vitro P-450 enzyme systems prepared from untreated and inducer-treated mice

\begin{tabular}{|c|c|c|c|c|}
\hline \multirow{2}{*}{ Group } & \multicolumn{2}{|c|}{$\begin{array}{c}\text { NADPH oxidation } \\
(\mathrm{nmol} / \mathrm{mg} \text { MS Pr./min) }\end{array}$} & \multicolumn{2}{|c|}{$\begin{array}{l}\text { Aniline hydroxylase activity } \\
\text { (nmol/mg MS Pr. } / \mathrm{min} \text { ) }\end{array}$} \\
\hline & Absence of RFP & Presence of RFP & Absence of RFP & Presence of RFP \\
\hline Untreated & $1.544 \pm 0.521$ & $1.587 \pm 0.561^{\mathrm{ns}}$ & $1.527 \pm 0.115$ & $1.491 \pm 0.107^{\mathrm{ns}}$ \\
\hline Phenobarbital & $1.924 \pm 0.571$ & $2.028 \pm 0.600^{\mathrm{ns}}$ & $2.056 \pm 0.195$ & $1.955 \pm 0.221^{\mathrm{as}}$ \\
\hline Rifampicin & $2.389 \pm 0.908$ & $2.559 \pm 0.776^{\mathrm{ns}}$ & $1.928 \pm 0.242$ & $1.837 \pm 0.258^{\mathrm{ns}}$ \\
\hline $\mathrm{CCl}_{4}$ & $0.389 \pm 0.176$ & $0.326 \pm 0.147^{\mathrm{ns}}$ & $0.331 \pm 0.056$ & $0.321 \pm 0.050^{\mathrm{n} s}$ \\
\hline
\end{tabular}

Microsomes were prepared from untreated, phenobarbital $(80 \mathrm{mg} / \mathrm{kg}$ for 4 days)-, rifampicin (RFP) (200 $\mathrm{mg} / \mathrm{kg}$ for 4 days)- and $\mathrm{CCl}_{4}(400 \mu \mathrm{l} / \mathrm{kg})$-treated mice. The concentration of $\mathrm{RFP}$ was $8 \times 10^{-6} \mathrm{M}$. Values represent means \pm S.D., $n=4-5$ animals. ${ }^{\text {ns }}$ not significantly different from the corresponding control values without RFP in vitro. 
enzymes to some extent in mice. These results are different from those of a previous study that showed that rifampicin did not induce the mixed-function oxidase in rats (5). Whether this discrepancy is due to the species difference in experimental animals used in the two studies is not clear at present.

It is known that the inducers of microsomal drugmetabolizing enzymes can potentiate the hepatotoxicity of xenobiotics such as acetaminophen and $\mathrm{CCl}_{4}$, which are biotransformed to active metabolites by the liver mixed-function oxidase system, as it has been reported that patients on treatment with acetaminophen experienced hepatotoxic reactions with rifampicin, isoniazid and other agents for active tuberculosis (16) and that phenobarbital increased $\mathrm{CCl}_{4}$ hepatotoxicity (17). However, a significant protective effect of rifampicin against $\mathrm{CCl}_{4}$-induced liver injury was found in this investigation. In mice treated with $\mathrm{CCl}_{4}$ alone $(50-400 \mu \mathrm{l} / \mathrm{kg})$, serum ALT and AST activities were increased and reached 281 and 272 I.U./1, respectively, at $400 \mu \mathrm{l} / \mathrm{kg}$ of $\mathrm{CCl}_{4}$, while cotreatment with phenobarbital raised them further to 532 and 460 I.U./1, respectively. In both groups of animals, severe centrilobular necrosis was histologically found; Marked reduction in the contents of cytochromes P-450 and $b_{5}$, and the activities of NADPHcytochrome $\mathrm{C}$ reductase and drug-metabolizing enzymes with increasing doses of $\mathrm{CCl}_{4}$ were observed. In contrast, in mice cotreated with rifampicin $(200 \mathrm{mg} / \mathrm{kg})$ and $\mathrm{CCl}_{4}$, the activities of serum ALT and AST remained almost normal, and only hepatocellular fatty degeneration was observed; The decreases in the contents and the activities of liver microsomal enzymes induced by $\mathrm{CCl}_{4}$ were much less than those in $\mathrm{CCl}_{4^{-}}$or phenobarbital plus $\mathrm{CCl}_{4^{-}}$ treated groups. These results demonstrate a significant protection from $\mathrm{CCl}_{4}$ hepatotoxicity by pretreatment with rifampicin.

It is known that hepatotoxicity of $\mathrm{CCl}_{4}$ is caused by several of its active metabolites generated by $\mathrm{P}-450$. The primary step in $\mathrm{CCl}_{4}$ metabolism is reductive and consists of transfer of an electron to $\mathrm{CCl}_{4}$ by the $\mathrm{P}-450$ system yielding $\mathrm{CCl}_{3}{ }^{\circ}(18)$. There is also evidence for a two-electron reduction yielding dichlorocarbene, but this step seems to be quantitatively minor (19). These reductive steps are carried out by $\mathrm{P}-450 . \mathrm{CCl}_{3}{ }^{\circ}$ is a reactive species and yields a variety of secondary metabolites. Under certain conditions, $\mathrm{CCl}_{3}{ }^{\circ}$ reacts largely with polyunsaturated fatty acids by $\mathrm{H}^{-}$abstraction, forming $\mathrm{CHCl}_{3}$ and lipid free radicals or by covalent binding at site of a double bond, forming an adduct that is also a free radical (20). In the presence of oxygen, oxygen reacts with free radicals, and lipid peroxidation occurs with destruction of lipids causing liver cell damage. When oxygen reacts with $\mathrm{CCl}_{3}{ }^{\circ}$, it forms $\mathrm{CCl}_{3} \mathrm{OO}^{\circ}$, which may promote the des- truction of P-450 responsible for catalyzing $\mathrm{CCl}_{4}$ metabolism and generation of $\mathrm{CCl}_{3}{ }^{\circ}$. This limits $\mathrm{CCl}_{4}$ metabolism in the liver (21).

$\mathrm{CCl}_{4}$ hepatotoxicity is relieved by inhibition of hepatic microsomal enzymes. Lauriault et al. (22) reported that the thiol drug diethyldithiocarbamate and its two metabolites, disulfiram and carbon disulfide, could be used as inhibitors of $\mathrm{P}-450$ to protect hepatocytes from damage induced by $\mathrm{CCl}_{4}$. In contrast, $\mathrm{CCl}_{4}$ hepatotoxicity is increased by induction of $\mathrm{P}-450$. It was reported that $\mathrm{CCl}_{4}$-evoked liver injury was enhanced in phenobarbitalinduced animals (23). Noguchi et al. (24) further showed that the phenobarbital-inducible form of P-450 was capable of generating the trichloromethyl free radical in the reconstituted enzyme system. The present study also showed similar results in that phenobarbital considerably increased the amount of P-450 and the activities of drugmetabolizing enzymes, and it markedly increased liver degeneration and necrosis induced by a large dose of $\mathrm{CCl}_{4}$. However, liver injury was not significantly different from that in the controls following treatment with low doses of $\mathrm{CCl}_{4}$, and thus it seemed that the rate of biotransformation for a low plasma concentration of $\mathrm{CCl}_{4}$ in normal mice was similar to that in phenobarbital-induced animals.

The isoform of $\mathrm{P}-450$ that is responsible for the reductive activation of $\mathrm{CCl}_{4}$ has not been identified conclusively. Recently, anti-(P-450 2E1)-Ig G experiments performed with microsomes showed that addition of anti(P-450 2E1)-Ig G to the in vitro P-450 enzyme system was capable of inhibiting $\mathrm{CCl}_{4}$-mediated microsomal lipid peroxidation by $70 \%$, suggesting that $\mathrm{P}-4502 \mathrm{E} 1$ is involved in metabolic activation of $\mathrm{CCl}_{4}(25-27)$. Hepatocytes isolated from rats treated with pyrazole, which is an inducer of $\mathrm{P}-450$, were found to be much more susceptible to $\mathrm{CCl}_{4}$-induced cytotoxicity than those isolated from normal rats. Microsomal enzymes prepared from pyrazole-treated rats also underwent a $\mathrm{CCl}_{4}$-catalyzed lipid peroxidation with NADPH much more rapidly than microsomal enzymes from controls. Secondly, microsomal enzymes prepared from rats treated with pyrazole also showed enhanced aniline hydroxylation, whereas the activities of ethoxyresorufin $O$-dealkylase, which is somewhat specific for P-450 1A1/1A2; pentoxyresorufin $O$-dealkylase, which is specific for $\mathrm{P}-450$ $2 \mathrm{~B} 1 / 2 \mathrm{~B} 2$; and aminopyrine $N$-demethylase were not markedly altered. In addition, diethyldithiocarbamate, which is an inhibitor of microsomal enzymes, not only reduced lipid peroxidation and cytotoxicity of $\mathrm{CCl}_{4}$, but also depressed aniline hydroxylase (22). These findings indicated that aniline hydroxylase is specific, at least to a certain extent, for P-450 2E1.

As compared to the effects of phenobarbital on liver 
drug-metabolizing enzymes, rifampicin was less effective on aniline hydroxylase activity, which increased by $26 \%$ and $35 \%$ in rifampicin- and phenobarbital-treated animals, respectively, but was more effective on aminopyrine $N$-demethylase activity, which showed increases of $163 \%$ and $87 \%$ in rifampicin- and phenobarbital-induced mice, respectively. Furthermore, $\mathrm{CCl}_{4}$-dependent MDA formation was moderately elevated in the in vitro P-450 enzyme system from rifampicin-induced mice and was significantly enhanced in this system from phenobarbital-induced animals. These experiments indicated that both rifampicin and phenobarbital increased the activity of P-450 2E1 which catalyzed bioactivation of $\mathrm{CCl}_{4}$ as well as other isoforms of P-450. However, these results failed to explain why rifampicin did not increase but rather reduced liver injury caused by $\mathrm{CCl}_{4}$. To elucidate the protective mechanism of rifampicin against $\mathrm{CCl}_{4}$-induced liver damage, the inhibitory effect of rifampicin on lipid peroxidation caused by $\mathrm{CCl}_{4}$ was investigated in the in vitro mixed-function oxidase systems from untreated and inducer-treated mice. The lipid peroxidation generated by $\mathrm{CCl}_{4}$ was noticeably suppressed in the presence of rifampicin at varying concentrations from 2 to $32 \times 10^{-6} \mathrm{M}$ in the three enzyme systems described above. Meanwhile, another investigation also demonstrated that NADPH oxidation during $\mathrm{CCl}_{4}$ metabolism was markedly increased in the microsomal enzymes prepared from rifampicin- and phenobarbital-induced mice. However, NADPH oxidation was not inhibited by rifampicin at a concentration of $8 \times 10^{-6} \mathrm{M}$ in these enzyme systems. In addition, rifampicin was also incapable of inhibiting the activity of aniline hydroxylase in the in vitro microsomal enzyme systems. These suggested that in vitro rifampicin was unable to inhibit the bioactive metabolism of $\mathrm{CCl}_{4}$ catalyzed by $\mathrm{P}-4502 \mathrm{E} 1$ and to reduce free radical production.

Therefore, from the results of this study, the protective effect of rifampicin against liver injury induced by $\mathrm{CCl}_{4}$ was suggested to be due to direct inhibition of lipid peroxidation in liver cells as a result of free radicals generated by metabolism of $\mathrm{CCl}_{4}$. Although rifampicin accelerated the bioactivation of $\mathrm{CCl}_{4}$ by induction of P-450 2E1, its direct inhibition of free radical-mediated lipid peroxidation appeared to play the most important role in its effect on the $\mathrm{CCl}_{4}$ hepatotoxicity, i.e., antagonism of the effects of active metabolites of $\mathrm{CCl}_{4}$. There have been no similar reports published previously concerning the effects of inducers on $\mathrm{CCl}_{4}$ hepatotoxicity.

The antioxidant role of vitamin $\mathrm{E}$ has been wellreviewed. It has a similar protective effect against $\mathrm{CCl}_{4}$ hepatotoxicity (28), which is thought to exert its action through scavenging free radicals (29). GSH was a potent antioxidant and could markedly inhibit lipid peroxidation generated by $\mathrm{CCl}_{4}$-derived free radicals. As compared with the ability of GSH, the lipid peroxidation inhibitory effect of rifampicin was much more powerful than that of GSH. The $\mathrm{IC}_{50}$ of rifampicin on $\mathrm{CCl}_{4}$-mediated MDA formation in phenobarbital-induced microsomes of mice was 17 times lower than that of GSH. At present, it is not understood whether the lipid antioxidant activity of rifampicin is acting by direct scavenging of $\mathrm{CCl}_{4}$ derived peroxyl radicals or another mechanism. Our other study also revealed that rifampicin was able to reduce significantly liver injury and animal mortality caused by acetaminophen in mice (R. Huang et al., unpublished data), and studies on its protective mechanism are currently in progress in our laboratory.

\section{REFERENCES}

1 Ghent CN and Carruthers SG: Treatment of pruritus in primary biliary cirrhosis with rifampicin. Gastroenterology 94, 488-493 (1988)

2 Cynamon HA, Andres JM and lafrate RP: Rifampicin relieves pruritus in children with cholestatic liver disease. Gastroenterology 98, $1013-1016$ (1990)

3 Venkatesan K: Pharmacokinetic drug interaction with rifampin. Clin Pharmacokinet 22, 47-65 (1992)

4 Borcherding SM, Baciewicz AM and Self TH: Update on rifampicin drug interactions. Arch Intern Med 152, 711-716 (1992)

5 Adachi $Y$, Nanno T, Yamashita M, Ueshima S and Yamamoto $\mathrm{T}$ : Induction of rat liver bilirubin-conjugating enzymes and glutathione $S$-transferase by rifampicin. Gastroenterol Jpn 20 , $104-110$ (1985)

6 Lowry OH, Rosebrough NJ, Farr AL and Randall RJ; Protein measurement with the Folin phenol reagent. J Biol Chem 193, 265-275 (1951)

7 Omura $\mathrm{T}$ and Sato $\mathrm{R}$ : The carbon monoxide binding pigment of liver microsomes. J Biol Chem 239, 2370-2385 (1964)

8 Omura $\mathrm{T}$ and Takesue S: A new method for simultaneous purification of cytochrome $b_{5}$ and NADPH-cytochrome $c$ reductase from rat liver microsomes. J Biochem 67, 249-257 (1970)

9 Imai Y, Ito A and Sato R: Evidence for biochemically different types of vesicles in the hepatic microsomal faction. $J$ Biochem 60, $417-428$ (1966)

10 Nash T: The colorimetric estimation of formaldehyde by means of the Hantzsch reaction. Biochem J 55, 416-421 (1953)

11 Ullrich $\mathrm{V}$ and Weber $\mathbf{P}$ : The $O$-dealkylation of 7-ethoxycoumarin by liver microsomes. Hoppe Seylers Z Physiol Chem 353, 1171- 1177 (1972)

12 Nebert DW and Gelboin HV: Substrate-inducible microsomal aryl hydroxylation in mammalian cell culture. J Biol Chem 243, $6242-6249$ (1968)

13 Ernster L and Nordenbrand K: Microsomal lipid peroxdation. Methods Enzymol 10, 574-580 (1967)

14 Pineau T, Daujat M, Pichard L, Girard F, Angevain J, Bonfils $C$ and Maurel P: Developmental expression of rabbit cytochrome P450 CYP1A1, CYP1A2 and CYP3A6 genes. Effect of weaning and rifampicin. Eur J Biochem 197, 145-153 (1991) 
15 Daujat M, Clair P, Astier C, Fabre I, Pineau T, Yerle M, Gellin $J$ and Maurel P: Induction, regulation and messenger half-life of cytochromes P450 1A1, 1A2 and 3A6 in primary cultures of rabbit hepatocytes. CYP1A1, 1A2 and 3A6 chromosome location in the rabbit and evidence that post-transcriptional control of gene 1A2 dose not involve mRNA stabilization. Eur J Biochem 200, 501-510 (1991)

16 Nolan CM, Sandblom RE, Thummel KE, Slattery JT and Nelson SD: Hepatotoxicity associated with acetaminophen usage in patients receiving multiple drug therapy for tuberculosis. Chest 105, 408-411 (1994)

17 Suarez KA, Carlson GP, Fuller GC and Fausto N: Differential acute effects of phenobarbital and 3-methycholanthrene pretreatment on $\mathrm{CCl}_{4}$-induced hepatotoxicity in rats. Toxicol Appl Pharmacol 23, 171-177 (1972)

18 Recknagel RO: Carbon tetrachloride hepatotoxicity: An example of lethal cleavage. CRC Crit Rev Toxicol 2, 263-279 (1973)

19 Ahr HJ, King LJ, Nastainczyk W and Ulrich V: The mechanism of chloroform and carbon monoxide from carbon tetrachloride by microsomal cytochrome P-450. Biochem Pharmacol 29, 2855-2861 (1980)

20 Trudell JR, Bosterling B and Trevor AJ: Reductive metabolism of carbon tetrachloride by human cytochromes $P 450$ reconstituted in phospholipid vesicles: Mass spectral identification of trichloromethyl radical bound to dioleoyl phosphatidylcholine. Proc Natl Acad Sci USA 79, 2678-2682 (1982)

21 Williams AT and Burk RF: Carbon tetrachloride hepatotoxicity: an example of free radical-mediated injury. Semin Liver Dis 10, 279-284 (1990)

22 Lauriault VV, Khan S and O'brien PJ: Hepatocyte cytotoxicity induced by various hepatotoxins mediated by cytochrome
P-45 2E1: protection with diethyldithiocarbamate. Chem Biol Interact 81, 271-289 (1992)

23 Pani P, Torrielli MW, Gabriel L and Gravela E: Further observation on the effects of 3-methycholanthrene and phenobarbital on carbon tetrachloride hepatotoxicity. Exp Mol Pathol 19, 15-22 (1983)

24 Noguchi T, Fong KL, Lai EK, Alexander SS, King MM, Olson L, Poyer JL and Mccay PB: Specificity of phenobarbital-induced cytochrome P-450 for metabolism of carbon tetrachloride to the trichloromethyl radical. Biochem Pharmacol 31, $615-624$ (1982)

25 Ekstrom G, Von Bahr C and Ingelman-Sundberg M: Human liver microsomal cytochrome P-450 2E1. Immunological evaluation of its contribution to microsomal ethanol oxidation, carbon tetrachloride reduction, and NADPH oxidase activity. Biochem Pharmacol 38, 689-690 (1989)

26 Johansson I, Ekstrom G, Scholte S, Puzychi D, Jornvall H and Ingelman-Sundberg $M$ : Ethanol-, fasting- and acetone-inducible cytochrome $\mathrm{P}-450$ in rat liver: regulation and characteristics of enzymes belonging to the $2 \mathrm{~B}$ and $2 \mathrm{E}$ gene subfamilies. Biochemistry 27, $1925-1934$ (1988)

27 Johansson I and Ingelman-Sundberg M: Carbon tetrachlorideinduced lipid peroxidation dependent on an ethanol-inducible form of rabbit liver microsomal cytochrome P-450. FEBS Lett 183, 265-269 (1985)

28 Yoshikawa T, Furukawa $\mathrm{Y}$ and Murakami M: Effects of vitamin E on D-galactosamine-induced or carbon tetrachloride-induced hepatotoxicity. Digestion 25, 222-229 (1982)

29 Yurdakak M, Yurdakak K and Caglar M: Carbon tetrachloride poisoning. (Letter) Lancet 1, 1335-1336 (1985) 